Dr George Vasilev

Postdoctoral Research Fellow

School of Social and Political Sciences

University of Melbourne

3010

VIC

Australia

george.vasilev@unimelb.edu.au

George Vasilev is a postdoctoral research fellow at University of Melbourne, Australia. His research explores the application of deliberative democracy in the fields of conflict resolution, multiculturalism and transnational activism. He also does work on Balkan politics and Europeanisation. He is author of the book Solidarity across Divides (Edinburgh University Press). His research has been published in Review of International Studies, Ethnopolitics, Review of Politics, and Critical Review of Social and Political Philosophy, among other journals.

\title{
Methodological Nationalism and the Politics of History-Writing: How Imaginary Scholarship Perpetuates the Nation
}

The aim of this article is to contribute a greater understanding of the processes by which nationalism passes by unnoticed in research and distorts knowledge about the past. It identifies four narrative practices typical of methodologically nationalist history-writing and explains why they should be rejected as dubious scholarship. These are: concept overstretch; selection bias; the misrepresentation of governing bodies; and the conflation of culture with identity. It is argued that each functions as a hidden authentication route, entrenching nation-centric understandings of the past as valid perspectives in scholarly discourses under the legitimating cover of scientific protocol. By increasing awareness around methodological nationalism in historywriting, this article serves at least two normative purposes. First, it emphasises the reflectiveness required for analysts to avoid co-option by ideology. Second, it functions as a critical vantage point for dispelling misunderstandings that fuel interstate disputes, interethnic tensions, and the oppression of minorities among populations understanding themselves as heirs to timelessly national property.

Keywords: ideology; historical representation, methodological nationalism, nationalism

Wordcount: 10,997

This is the author manuscript accepted for publication and has undergone full peer review but has not been through the copyediting, typesetting, pagination and proofreading process, which may lead to differences between this version and the Version of Record. Please cite this article as doi: 10.1111/nana.12432

This article is protected by copyright. All rights reserved. 


\section{Methodological Nationalism and the Politics of History-Writing: How Imaginary Scholarship Perpetuates the Nation}

\section{Introduction}

In recent years, awareness has grown that methodological nationalism is an intellectual bad habit to be wary of. Across a variety of research disciplines in the social sciences, critically inclined scholars have exposed its ideological creep, laying bare the unexamined prejudices, presumptions of relevance, and value judgements that have inspired the adoption of the nation as a paradigm for understanding human relations (Beck 2000; Wimmer and Schiller 2003; Sager 2016; Scheel et al. 2016).

However, within the field of historical studies, the full impact of methodological nationalism is yet to receive the same theoretical treatment. There is, to be sure, a genealogically focussed literature documenting the nineteenth century rise of the modern historian and the profession's role in producing propagandist histories. This work documents the 'historiographical nationalism' (Berger 2015) of academic professionals closely connected to states and nationalist movements of the time. It notes how their idealised historical accounts provided the intellectual foundations for justifying the establishment of new nation-states and the expansion of ones that already existed (Billig 1995; Lawrence 2013; Berger 2015; Storm 2018). 
There is also a temporally focussed literature that contemplates the moment when nations first emerged as a specific kind of human association (Breuilly 1996; Smith 2004; Özkirmli 2007; Leerssen 2014). This work draws attention to the 'retrospective nationalism' of scholars who, under the spell of ideology, backdate contemporary nations to periods before their actual existence.

Finally, an empirically focussed literature provides a rich narrative account of the above phenomena through individual case studies and comparative analyses with indepth and detailed knowledge of specific contexts (Danforth 1995; Özkirmli and Sofos 2008; Sand 2010). This work highlights the partisan historiographies that have served as social engineering instruments for states seeking to inspire loyalty from the masses and homogenise culturally diverse and nationally unaware populations.

However, although this voluminous body of research notes the intimate relationship between nationalism and historical research, it does not explicitly theorise methodological nationalism. Indeed, there is no systematic conceptualisation of the phenomenon that unpacks the mechanics behind the production, dispersal and uptake of naturalisations that imbue nations with an omnipresence going back in time. What is missing is a deeper level methodological probing to explain how the nation becomes a taken-for-granted unit of historical interpretation, how such research passes muster during peer review to be published in prestigious academic outlets, and 
how it shapes and is itself shaped by the opinions and beliefs circulating in the wider public sphere.

In this article, I fill this gap in theorisation. I aim to contribute a greater understanding of the processes by which nationalism passes by unnoticed in research and distorts knowledge about the past. I identify four narrative practices typical of methodologically nationalist histories and explain why they should be rejected as dubious scholarship. These are: concept overstretch; selection bias; the misrepresentation of governing bodies; and the conflation of culture with identity. I explain how each functions as a hidden authentication route, entrenching nationcentric understandings of the past as valid perspectives in scholarly discourses under the legitimating cover of scientific protocol.

To illustrate these practices, I focus primarily on research representing historical episodes prior to the late eighteenth century, directing my criticism at scholars who argue nations have 'premodern' origins. I put to one side research on subsequent historical periods while acknowledging it too has been impacted by various forms of methodological nationalism. There are three reasons of normative significance behind my choice to circumscribe the scope of cases in this way.

First, historical writing depicting events before the late eighteenth century continues to routinely treat the nation as obvious and natural, despite growing awareness that 
such practice is ideological hegemony at work. The shelves of university libraries and articles published in academic journals bear testament to this, containing numerous contributions giving nations and nation-like phenomena centre stage in the events of antiquity and the medieval period (e.g., Hastings 1997; Grosby 2005; Kaplan 2005; Roshwald 2006; Kaldellis 2007; Woolf 2007; Gat 2012; Hirschi 2012). Despite the repeated exposure of their flaws (e.g., Breuilly 1996; Hansen 2006; Özkirmli 2007; Lawrence 2013; Leerssen 2014) and despite historiography's transnational turn in recent decades, such works continue to be cited widely and accepted as having something reliable to say about what the past was like.

Second, official and popular understandings of history are themselves overwhelmingly methodologically nationalist, deriving from, but also inspiring, nationalism within the scholarly realm. Indeed, state sponsored narratives depicting regions, symbols, historical civilisations, empires, artwork, architecture and cuisine as irrefutably national property continue to be a daily intrusion on lives across the globe, so much so that the ubiquity and formative power of those narratives frequently escapes people's attention (Storm 2017).

Finally, methodological nationalist histories can stimulate interstate disputes and human rights violations against minorities when they gain wide currency. In places where historical discourses reinforce an assumption of nations as perpetually present, a mindset of entitlement can emerge over a geographical space, increasing the 
likelihood of zero-sum territorial claims, securitised minority-state relations, and assimilatory policies against ethnic groups perceived as cultural threats (Danforth 1995; Sand 2010).

Increased awareness around methodological nationalism's role in shaping research agendas and reproducing flawed knowledge responds to these problems by instilling the reflectiveness required for analysts to avoid co-option by ideology. It also functions as a critical vantage point for dispelling misunderstandings in public debates that fuel interstate disputes, interethnic tensions, and the oppression of minorities wherever populations have been socialised to understand themselves as heirs to timelessly national property.

I begin the article with a general description of methodological nationalism before moving on to conceptualise it in detail specifically within the field of historical inquiry.

\section{Methodological nationalism}

Methodological nationalism is research carried out under the premise that national identification is a fundamental aspect of human nature. Those inclined to think this way make sense of the world through reductions of complexity that naturalise the nation as a self-evident window onto the world. Research tasks are approached with 
the conviction that 'humanity is naturally divided into a limited number of nations', that 'society' equates with 'nation-states', and that the cornerstone of social scientific analysis is national governments and the competition that takes place between them (Beck 2002: 51-52).

Under this social science repertoire, a 'national container theory of society' is perpetuated (Beck 2000). The researcher sets national boundaries on statistical indicators, categories of perception, and research procedures. Consequently, he/she neglects the significant ways that households, families, social class, inequality, democracy, commerce, power, governance, justice, law, among other institutions and relations of power, are shaped by interdependencies existing below and above the nation-state (Beck and Sznaider 2010: 386).

Methodological nationalism reflects and reinforces the researcher's prior identification with nations and states (Wimmer and Schiller 2003: 576). However, it is not necessarily guided by partisan intent. For scholarship to be compromised by nationalism, the researcher does not have to be motivated by a patriotic desire to portray the nation in a favourable light. Nor does he/she have to be engaged in acts of deception, such as the finessing of data sets, casuistry or other intentional forms of malpractice intended to give the nation an artificial presence in the field of investigation. On the contrary, methodological nationalism can be guided by a rationale that is impeccably truth-seeking. The researcher can be submitting 
him/herself entirely to the force of facts and logic and yet still arrive at a one-sided conclusion that nations hold the key to understanding what took place in the past, what is happening in the present, and how we ought to act in the future.

What makes such research into instances of methodological nationalism is the unexamined ontological and epistemological choices brought to bear on the analysis. If those choices are a mere reflection of surrounding ideological forces emanating from nation-states, then the analysis has been compromised before it has begun. The hierarchies of common-sense informing judgments on who are relevant agents to give voice to (ontology) and what is relevant information to include (epistemology) privilege nationhood ahead of other ways of being social and political. The reliance on this unacknowledged evaluative platform, in turn, leads to the formulation and resolution of research problems within national terms of reference. This sets in place a positive feedback loop that sustains nationhood as a common-sense medium through which to comprehend, theorise, and document social reality.

Understood in this way, methodological nationalism should not be confused with the mere study of nations and states. There are sound reasons for making national phenomena the focal point of historical, descriptive, explanatory and normative inquiry, as national affiliations have profoundly shaped people's view of the world and continue to determine how people interact with one another. Indeed, despite the global scope of today's ecological, economic, technological, security and moral 
threats, and despite the cosmopolitan outlooks stimulated by the urgency of those threats, human relations remain stubbornly nation-centred. Murderous violence is committed in the name of nations, individuation takes place through national distinctions, and states invest vast resources into promoting national interests. To the extent that nations and states remain salient levels of reality, their acknowledgement is unavoidable when conceptualising social phenomena, narrating events, and reasoning about the most justifiable policy responses, regardless of how desirable or objectionable one might find nationhood as a mode of solidarity.

By the same token, research can be, and frequently is, distorted by the failure to distance oneself from the familiarity of nations when generalising about the social world and idealising about how it can be more just. The term 'methodological nationalism' refers precisely to this blind spot. The analyst unreflectively accepts nations as a universal starting point of interpretation and reasoning when that universality is unwarranted. In this situation of scholarly naivety, conclusions are drawn that empirically and normatively overstate nations, while alternative subjectivities that matter in people's lives are overlooked. These subjectivities are relegated to the margins of analytical and policy significance in prior judgements about what is relevant (Hansen 2006: 23, 73).

The self-reinforcement of this research practice is captured aptly by Mark Twain's quip: 'To a man with a hammer, everything looks like a nail'. By holding the 
nationalist hammer, the analyst sees national actors everywhere and ascribes national purposes to all events deemed worthy of narrative inclusion. National belonging is regarded as the true essence of people's inner selves, locking in a pattern of thought that conceives problems and solutions in blinkered national terms.

Such writing is not simply reporting on ideology; it is also an instrument of ideology's reproduction. It is recognising the motives and interests of some agents and denying those of others (Dryzek 1988: 711). It thereby mirrors and further embeds a predominant understanding of what is natural and unnatural in political relations.

In what follows, I elaborate on the four methodologically nationalist practices specific to historical inquiry. Each practice, I show, reinforces the nation's self-evidence by laying out a chain of events that creates a false world of national communities enduring through epochal change.

\section{Concept Overstretch}

'Concept overstretch' is the expansion of a working definition to the point that it is deployed in an excessively broad way. Giovanni Sartori famously highlighted the problems that arise when a concept's range of meanings is stretched too far. Chief among them is the loss of discriminatory power required for relevant comparisons. In 
striving overzealously for temporal and spatial applicability, the analyst formulates a conceptual container deprived of the capacity to distinguish between significantly different phenomena. Consequently, he/she wonders through a fog of pseudoequivalences in which 'all the cows look black (and eventually the milkman is taken for a cow)' (Sartori 1970: 1040).

In the context of nationalism studies, concept overstretch involves the expansion of the term 'nation' to encompass many types of human relations prior to the eighteenth century and therefore prior to the period when nationalist ideology was available to sustain the types of affiliations characteristic of nations today. Justifications for this coding choice begins with the refrain that current uses of 'nation' are too restrictive due to their rootedness in the 'modern' period. They conclude with an appeal to open up the concept so that it incorporates human associations found in 'premodern' times and therefore captures what is supposedly the proper extent of national experience.

For Woolf, the attainment of this conceptual optimum requires jettisoning such 'modernist' criteria as 'mass public culture', 'single economy', and 'common rights and duties' as necessary factors. In his view, nations should be conceived simply as 'a named human population occupying a historic territory or homeland and sharing common myths and memories' (2007: 76). This is a stripped down version of a more comprehensive definition originally formulated by Anthony Smith (1991: 14), containing only the attributes Woolf endorses as 'more helpful' (76). 
For Hastings, it requires parting ways with the 'modernist' conceptions of Eric Hobsbawm, John Breuilly, Ernest Gellner and Benedict Anderson and prioritising, instead, 'an extensively used vernacular literature' as a key criterion. Hastings dismisses the conceptual framework of these theorists as 'somewhat weak on hard history' (1997: 2) and touts his own framework as better equipped from both a descriptive and explanatory perspective. As he puts it, an extensively used vernacular literature is 'by far the most important and widely present factor' in the development of nationhood (2-3). It is supposed to not only indicate the presence of a nation, but also explain what causes a nation to appear.

For Roshwald, arriving at the optimal conceptual breadth entails doing away with the 'overly narrow' criterion of 'striving for self-determination...in the name of universal principles' and prioritising, instead, a 'preoccupation with freedom, political territorial sovereignty and dignity' (2006: 10-11). According to him, these latter characteristics are 'the essence of nationalism' and therefore direct us to nations wherever they existed in the 'premodern' past (11).

Grosby also bemoans the inhibiting tendencies of 'modernist' definitions and offers a particularly thoroughgoing relaxation of the concept in response. He declares, undemandingly, that a nation is simply 'a territorially formed "people" that is believed to have existed over time' (2005: 10). 
What is immediately striking about these reconceptualisations is their circularity. The authors self-servingly construct a definition most amenable to advancing their disputed standpoints about the pre-eighteenth century origins of nations. It is in this vein that Woolf reasons Machiavelli "formulated some kind of notion of "Italy" that approximates a nation' (2007: 77) and that Machiavelli's near contemporary, Celtis, likewise had 'some form of consciousness of German nationality' (77) centuries before the materialisation of modern nation-states.

Similarly, the use of a permissible conception of nationhood emboldens Hastings to assert that England 'most clearly manifests in the pre-Enlightenment era, almost every appropriate "national" characteristic' and that 'an English nation-state survived 1066 [the Norman Conquest]' and 'grew fairly steadily in the strength of its national consciousness through the later twelfth and thirteen centuries' (1997: 4-5). It also allows Roshwald to claim that 'ancient Jews developed a recognizably national form of identity and indeed, that they were not the only ancient society to do so' (2006: 11). Grosby, with the most promiscuous definition, is galvanised to go the furthest with the backdating of nations, asserting that 'large, territorially distinct societies can be observed from our first written records' (2005: 1).

To the uninitiated, these findings might appear as groundbreaking discoveries that upend conventional wisdom on the origins of nations. But it does not take much to see 
that they are mere semantic manouvres that add nothing fresh to historical knowledge. An impression of national continuity is generated through the fudging of meanings and the subsequent drawing of pseudo equivalences between historical and contemporary populations. While vernacular literatures, territorial sovereignty, and myths and memories can be documented in the deep past, these observations reveal nothing about the presence or absence of nations. This is because a variety of identities can materialise around such collective practices, all of which are not necessarily national (see below). By postulating a likeness on the basis of the above collective practices alone, the analyst stretches the term 'nation' so far that it becomes a coding device in which the unlike look alike across immense cultural and temporal differences. Such overstretch, in which 'fish' might be termed 'humans' due to a shared swimming capability (Sartori 1970: 1052), sets narrations on a course of analytical impoverishment, imprecision and obfuscation.

The scholarship of these historians is unedifying if only because it presumes shared meanings can be remade by design and through an act of individual discretion. To declare that, henceforth, a familiar understanding of the nation will be replaced with one's own novel sense of the word is reminiscent of Humpty Dumpty's fabled exchange with Alice, where he tells her: 'When I use a word, it means what I choose it to mean' (Caroll 1990). Such practice obstructs communication by forcing onto language private meanings. As Wittgenstein (1922) highlighted, what words say depends on their context of most significant use. Words do not carry an inherent 
property that one hits upon through tenacious digging and solitary musing. Their intelligibility is derived from how they are routinely put to work. The achievement of analytical clarity therefore depends on observing these pragmatics of communication.

Historians who are describing something different to what the term 'nation' signifies among their peers should opt for an alternative label to make this difference apparent. They should avoid indulging in arbitrary determinations of sense that bloat the concept beyond its familiar employment and therefore introduce confusion into historical explanation.

\section{Selection Bias}

'Selection bias' refers to the process of deriving generalisations from a statistically unrepresentative sample of cases (Collier 1995: 462). In this situation, the fact-finder provides evidence that appears irrefutably to show that nations were a relevant form of human organisation in the ancient and medieval periods. However, on closer inspection, it is apparent he/she is studying only a narrow band of individuals, typically an elite stratum, whose characteristics were not shared by broader populations and therefore do not demonstrate the society in question was a nation (Sand 2010: 315-316). 
Such writing gives the impression of thorough research, consisting in detailed archival analysis and 'close readings' of original documents. However, it produces parochial knowledge by misrepresenting the dispositions of the historical few as the dispositions of the historical many. Through the activity of historical speculation, information gaps are filled with a contemporary doctrine the researcher is programmed to see. The result is a web of national stories woven together from a series of cavalier generalisations about the national things people were supposedly thinking and doing at the time being represented.

Kaldellis' (2007) Hellenism in Byzantium offers an illustration. In this book, Kaldellis argues Byzantium 'was not "a universal, Christian, multiethnic empire" as all think today, but a nation-state like most modern nation-states' (5). Its identity was supposedly based on Hellenism, which Kaldellis asserts was first articulated as a national ideal in ancient Athens and revived once again in thirteenth century Byzantium, where it 'acquired the weight of national discourse and complemented the rhetoric of New Rome' (5). Kaldellis defends his 'new thesis' by highlighting the fondness influential figures within Byzantium showed towards 'the classical Greek legacy' (5). These Byzantine Hellenists, he writes, 'had closer access and a greater stylistic affinity to the classics than has been possible ever since' (5). They also apparently embraced 'a cultural vision of Hellenism', which was a prominent part of the period's 'advancement of learning' and 'high culture' (5). These developments, 
according to Kaldellis, point to the Hellenic national consciousness that prevailed in the Byzantine context.

However, Kaldellis' book is a study of a detached aristocratic and intellectual community - namely, the imperial and educated elites in the city of Constantinople. The cultural centrism of this exclusive sample is not representative of the broader Byzantine population. Beyond those elites and their city, and in the empire's far-flung provinces, antiquity and its intellectual inheritance had an alien quality. The 'Hellenes' were interpreted as a mythical race of giants in a distant past, as opposed to an ancient people from whom one descended and drew pride (Greene 2015: 47).

Furthermore, rather than having a unifying impact, the appropriation of Hellenic culture introduced a relation of difference within Byzantium. Among the Constantinopolitan elite, proficiency in the ancient Greek language conferred high social prestige and was therefore actively pursued. Yet this elevation in social status was beyond the reach of ordinary people, as they lacked access to education in the language. Their use of demotic Greek, the everyday vernacular of the period, was a source of derision among the elites, who likened it to barbarised speech and a form of cultural otherness (Greene 2015: 46). The social distancing of Hellenism was further accentuated by the regional identities beyond Constantinople, which rivalled the sense of being an imperial subject (Greene 2015: 47). In these territories, belonging was 
distinctly local, supplanting the imperial loyalty witnessed among Constantinople's aristocrats.

In sum, Kaldellis succeeds in associating Hellenism with Byzantium because of the narrow scope of his sampling and not because most of Byzantium's inhabitants were under the thrall of that ideology or coexisted as a compact community resembling a Hellenic nation. He omits vast segments of the population from consideration, producing findings that magnify the relevance of Hellenism in the public life of Byzantium and its system of government. A consideration of subjects beyond Kaldellis' narrow sample reveals that fragmentation, not unity, characterised the late Byzantine Empire. It also reveals that Hellenism's ideological utility was marginal, dwarfed by the vast material and symbolic investment the empire put into Orthodox Christianity. And yet, even religious identification, despite being an essential component of the empire, did not sustain a close-knit community of members bound by common interests that one could call a nation. The Orthodox Christian world encompassed not one but many Orthodox Christian societies distinguishable by linguistic differences and ties to specific regions (Greene 2015: 48-49).

Another version of selection bias typical of methodologically nationalist work is the use of scattered quotes or incidental remarks from the past that falsely attribute a national significance to a period's agents. Quentin Skinner described such practice derisively as the 'mythology of doctrines' (1969: 12). The historian collects 
fragmented thoughts, typically from a classic writer, finding messages and extrapolating meanings from them through a preconceived doctrine. The result is the historian's own prejudices being fixed onto the writer, given that the historian is more interested in the retrospective significance of the thoughts, rather than their significance for the writer him/herself.

An example of this practice is Woolf's attempt to extract a national message from Machiavelli's works. According Woolf, 'it is possible to read nationalism into [Machiavelli's] narrative (2007: 77) and to detect an 'ambient sentiment that can be called nationalist' in Renaissance Europe (77). Woolf directs attention towards Machiavelli's presumption of 'some binding commonality between the various independent cities and princely states of the early sixteenth century' (77), and concludes that 'to dismiss the idea of the nation (or of a nation) as being irrelevant to the reading of an author simply because he came too early... is overly ascetic' (77).

Woolf does not quote Machiavelli directly. However, Woolf's views are probably developed from a reading of the final chapter of The Prince, where Machiavelli makes an appeal to Italian patriotism. At first glance, the title of that chapter 'An exhortation to liberate Italy from the barbarians' and the chapter's lyrical reference to 'the virtue of an Italian spirit' do indeed appear as telling glimpses of a nationalistic mindset. However, an appreciation of the context surrounding these venerations of Italy reveals they were not motivated by a sense of national devotion, much less a national 
conception of Italy, but rather, by a desire for the imperial expansion of Florence, Machiavelli's own city-state and the object of his political loyalties.

In Machiavelli's time, Florence was undergoing a steady decline following a period of political and cultural dominance. Its ruling Medici family was also facing the threat of the encroaching Valois and Habsburg dynasties. The Prince is a work aimed at reviving Florentine hegemony in the face of these developments, but reconstituting that hegemony in the image of the ancient Roman Republic, which Machiavelli eulogises throughout his works as a role model of strength and liberty (Hörnqvist 2004: 263).

Taken against this backdrop, Machiavelli's repeated invocation of Italia is a façade for Florentine imperialist aspirations. It is a plea to the city-states of the Italian region to see their interests as best served under the authority of a Florentine empire headed by the Medici family, rather than submission to alternative imperial powers vying for the territory. It is also an exhortation to the Medici family, the addressees of the final chapter of The Prince, to embark on the conquest of Italy, a call to action Machiavelli couches in terms of divine providence, just war and a quest for peace, rather than national self-determination (Hörnqvist 2004: 262).

Used in this fashion, 'Italy' carries a regional and cultural meaning, much like 'Scandinavia' or 'Europe' does today. Recourse to it is intended to exalt a preferred 
set of rulers as 'native' and 'benevolent' and to diminish a rival set as 'foreign' and 'aggressive', all for the grander purpose of legitimating a desired type of order over a coveted territory. An appeal to unity of this kind is neither an outpouring of national patriotism nor an ambition for the national form of statehood that emerged in Italy centuries later. While it implies commonalities based on culture and geography, these are no more an expression of national consciousness than are the cultural and geographic commonalities invoked by Robert Schuman and the other founding fathers of the European Union to justify its creation or the leaders of Scandinavian states to justify the creation of the Nordic Council.

In the end, if Machiavelli was aware of nationalism and if it was important in his time, it is nowhere to be seen in his writing. He never explicitly articulated the doctrine, leaving contemporary historians to reconstruct it from fragmented quotes and vague hints. This can be contrasted with Machiavelli's full awareness of republicanism. The Prince is a step by step defense of the doctrine modelled on classical Rome and inspired by its political successes. In the face of such a discrepancy, it is only plausible to conclude that Machiavelli never was guided by nationalism. The historian who argues otherwise is, in the words of Skinner, foreshortening 'the past by filling it with his own reminiscences' (1969: 27).

\section{The Misrepresentation of Governing Bodies}


Another way methodological nationalist scholarship naturalises nations is by misrepresenting historical governing bodies as carriers of ethnic or national identities. Under the influence of autobiographical narratives promoted by contemporary nationstates, writers see precursors of these states in the medieval and ancient periods. Swept away by this mythologising, they proceed to depict historical empires, kingdoms, city-states, and religious institutions as ethnic and national possessions. They also depict the political actions of historical kings, princes, tsars, sultans, khans and feudal lords as motivated by a concern to promote interests tied to ethnic and national communities - much like the governments of contemporary states - when in fact entirely different rationales were guiding their political pursuits.

This form of misrepresentation can be illustrated through writing on Israel and Greece, which contains frequent references to supposedly hereditary governing institutions dating back to ancient times. According to Grosby, 'All nations have historical antecedents, whether tribe, city-state, or kingdom' (2005:8). In the case of ancient Israel, he identifies the 'Jerusalem Temple' (10), 'the kingdom of David and Solomon, 'the northern kingdom of Israel', and 'the southern kingdom of Judah' (73) as examples of such antecedents. Such institutions are supposed to have provided a 'structure for the nation' (10), encompassing a 'ruling centre' that propagated a 'territorially unifying religion and law' (70). 
Roshwald builds on Grosby's findings, quoting passages from the Hebrew bible and invoking imagery on coins from the second century $\mathrm{CE}$ as proof that an 'institutional and ideological nexus' bearing 'all the hallmarks of politicised, national-territorial identity' existed in ancient Israel (2006: 16). He extends this analysis to Greece, arguing that ancient Athens also qualifies as a nation-state, or more precisely, a 'nation-polis' (27), given that it embodied 'love of country', 'popular sovereignty' and a sense of 'distinctive character', among other 'quintessential elements of nationalism' (25). He also argues that a 'budding pan-Hellenic national consciousness' (22) glued the city-states together despite their devastating wars. $\mathrm{He}$ supports this view with quotes from the historian Heroditus, who in his writing from the fifth century BC, documented appeals to an 'idea of collective Hellenic heritage' when joint resistance was urged among the city-states against the invading Persians (27; see also Kaldellis 2007: 13-41).

The continuity between past and present traced by this writing is spurious because the ancient and medieval political actors it represents were not functional equivalents of contemporary states. Prior to the eighteenth century, sovereigns did not rule in the name of 'the people', but rather, in the name of religion or civilisation. The empires, dynastic kingdoms, city-states, and tribal confederacies that went to war did so over the balance of power between them or to bring a desired successor to the throne, but not to achieve ethnic and national aggrandisement (Wimmer 2013: 1-2; see also Breuilly 1993: 76). The 'deep horizontal comradeship' (Anderson, 2006: 7) definitive 
of national communities was absent in this world. Peasants identified with peasants and nobles with nobles. Such class distinctions intersected with local affiliations based on village, town, clan and place of worship. In this setting, little attention was paid to one's own ethnic background, much less to that of one's rulers (Wimmer 2013: 1).

Government through centralised bureaucracy did exist. However, it did not aim to recreate culturally populations in the image of an ethnic or national ideal, an obsession of contemporary governments hoping to generate loyalty and cohesion among citizens through cultural homogenisation. Instead, the apparatus of coercion was put to the tasks of maintaining internal order, enforcing compliance with laws, and facilitating the collection of taxes (Özkirmli 2007: 524-525). Beyond this, rulers placed few demands on their subjects. Socialisation and control were handled locally through kinship ideologies and membership in families, villages and religious institutions. Wars tended to be fought with professional armies. Unlike in national societies, fighting and dying for one's country was not considered a moral duty (Eriksen 2002: 103-104).

It is only with the appearance of the first nation-states - Great Britain, the United States and France - from the late eighteenth century onwards, that ethnic and national logics become apparent as legitimating principles of rule. The notion that 'elites and masses should identify with each other and the rulers and ruled should hail from the 
same people' (Wimmer 2013: 4, 79) replaced imperial, dynastic, aristocratic and theocratic notions as a primary principle through which states organised themselves and justified their authority over territories. It is in this period that the pursuit of nationally conceived objectives first became a major source of interstate war and prompted governments to partake in irredentism, population expulsions, ethnic cleansing, assimilation and inter-ethnic power-sharing. This transformation in sovereign power unfolded as a cascade of nation-building that dramatically altered the political face of the globe in the recognisable form of today (Wimmer 2013: 4-5).

The point can be made with reference to Israel. The kingdoms, laws, moral codes and symbolism that prevailed over ancient Israel might resemble the political and social structures of nation-states. However, those structures were in fact faith oriented as opposed to ethnonational (Özkirmli 2007: 525; Breuilly 2008; Sand 2010). That is, they were jurisdictional and moral boundaries that differentiated between believers and non-believers of a Jewish religion and not between insiders and outsiders of a Jewish ethnicity.

Moreover, the governed populations named as Jewish lacked the cohesiveness implied in modern writing representing them through the prism of the nation. Religious grounding might have been a shared feature of belonging. However, beyond adherence to God's word, there is no indication that populations were compelled to conform with an obligatory societal culture or to identify with institutions embodying 
a 'people's will'. The ruling elites spoke Aramaic, the majority of their subjects expressed themselves in a range of Hebrew dialects, and business was conducted in the Greek koine (Sand 2010: 315). Ideological identification with the administrative apparatus was strong only among a thin stratum of the population benefitting from the dynastic and theocratic system of rule. This typically comprised the landed nobility and urban elites. Among the illiterate and the laboring classes, which constituted a significant proportion of the population, such ideological adherence appears to have been weak or non-existent (Sand 2010: 315).

For similar reasons, it is mistaken to consider ancient Greece an exemplar of national sovereignty. As a city-republic, Athens lacked the scale, complexity and social heterogeneity common to a national constituency. The polis was a small and compact community of a few thousand people living closely together, either within the urban center or surrounding countryside (Held 2006: 12).

Crucially, citizenship was highly exclusive, extended to a fraction of the population residing within the jurisdiction of the polis: Athenian men over the age of 20. Under this extremely selective citizenship regime, eligibility was denied to women, minors, immigrants (even those whose families had settled in Athens generations earlier) and slaves, who outnumbered free citizens by at least 3:2. With such striking discrimination, classical Athens can be likened to a closed club (Cartledge 1993: 4), a tyranny of citizens, and a democracy of the patriarchs (Held 2006: 19), but not a 
nation. The exclusion of vast categories of individuals from the affairs of the state and access to civil rights is irreconcilable with the concept of nationhood, which denotes relations of fellow-feeling across class lines and ties of responsibility that are blind to birth privileges.

Furthermore, although a shared political culture connected this enfranchised few, it did not display the hallmarks of nationalism. The Athenian concept of citizenship was premised on a commitment to the republican principle of civic virtue; that is, 'dedication to the republican city state and the subordination of private life to public affairs and the common good' (Held 2006: 14). In contemporary political thought, this principle has been appropriated to furnish models of citizenship concerned with protecting and promoting a national culture over territorially bounded communities (e.g., Miller 2008). However, this is not how the principle was envisaged in classical Athens. The polity did not have built into it a particularism based on historical destiny, imagined blood relations or a belief in common origin, despite the severity of membership restrictions that denied vast numbers of individuals access to powers of government.

Instead, the primary value attached to participation in the public life of the city was the promise of securing individual self-realisation. Athenians defended their direct democracy on the grounds that it was the superior alternative for fulfilling one's role in the universe and living an honourable life against the oligarchic and autocratic 
systems of rule in the surrounding city-states. Face-to-face political interaction in a strong and secure state was regarded as a route to this idealised end goal due to the perception that it opened up spaces for satisfying needs, pursuing one's calling, and, above all, acquiring such virtues as wisdom, courage and temperance (Held 2006: 14$15,26)$. The denial of citizenship to so many people safeguarded the integrity of this democratic way of life and its high aspirations for human autonomy and flourishing. There is no evidence that the overriding motivation of exclusionary citizenship was the nationalistic desire to secure the ethnic purity of state and society, a feature of contemporary naturalisation policies defined by stringent membership requirements. Without any indication of a discourse among the ancients venerating the state on national grounds and conceiving citizenship as an ethnic entitlement, there remains no basis for positing that classical Athens was a national political community.

The claim that ancient Hellenism was a nationalist movement is even more farfetched. It confuses a civilisational construct with a national one. Civilisational boundaries can be no less vivid than national ones in the minds of people classifying the world through crude cultural essentialisations (e.g., Huntington 1993). However, it is important to distinguish between the two, as they are premised on distinct forms of social closure. Civilisational identity is the broadest level of 'we' feeling between people. It embodies a symbolic frontier 'short of that which distinguishes humans from other species' (Huntington 1993: 24). Moreover, at its heart are hierarchies of cultural superiority that establish canons of taste and value in opposition to a primitive 
or barbaric outside (Said 2003). In this sense, civilisational identity exists in spite of the state-seeking enterprise of nationalism and the dense relations of obligation experienced in national communities. It is a higher level of collective abstraction forged in opposition to individuals cast as lesser humans owing to their presumptively inferior customs, mindsets or ways of life.

Distinctions between 'Europe' and 'the Orient', the 'Old World' and 'New World' or 'Islam' and 'the West' are familiar manifestations of such civilisational constructs in recent history. Each distinction denotes a field of cultural evaluation removed from a national logic, encompassing a wide array of states, ethnicities, languages, ideologies, religions, values, customs and regions. Yet despite this internal diversity and detachment from an overarching institutional system, the conception of selfhood behind each civilisational distinction has been imagined in stark terms. It has been employed as a horizon of justification to conquer, colonise, dominate and, in some cases, annihilate populations evaluated as inherently backward, implacably threatening and incompletely human.

This pattern of civilisational identification was apparent in ancient Greece. Hellenism was a collective abstraction that overlapped with prior affiliations found within the separate city states and kingdoms. It was never institutionalised as a guiding ideology in the governing structures of the time to fashion a conception of sovereignty. It remained, instead, a politically ungrounded cultural construct that served as an 
automatic badge of superiority. 'Greeks', which comprised a myriad of societies with diverse dialects, religions and mores dispersed throughout the Mediterranean and Asia minor, asserted the Hellenic badge as a standard of civilisation. It was how they marked themselves off from 'barbarians', the remainder of human kind whose speech was incomprehensible (Cartledge 1993: 11).

This is not to say that Hellenism was completely devoid of institutional expression. On the contrary, like other varieties of civilisation, it was rooted in a complex of written and unwritten social norms, roles, rituals, and even material entities that were enduring features of social life. Pan-Hellenic games were held quadrennially at Olympia and managed by a council of representatives from the main cultural and geographical divisions of the Greek world. Sites of religious worship located in Olympia and Delphi provided spiritual sanctuary for people across cities and regions. Texts were passed down intergenerationally that had a foundational status within Hellenic culture, such as Iliad and Odyssey (Cartledge 2009: 190-202). These transsocietal spaces and interrelationships reproduced a sense of overarching affiliation that complemented particularistic affiliations.

However, the symbolic frontiers of Hellenism and its civilisational hubris never acquired the prescriptive coherence of a nationalist movement. If nationalism is the desire to make the borders of the state coterminous with the borders of an ethnic community, it was nowhere to be observed as a chief medium of political action. Not 
only was 'Hellene' a cultural unit of a different order to an ethnic community, the vast space and diverse populations that spanned the Hellenic world were defined as much by their competitiveness and acrimony as by any willingness for cooperation and shared political life. As Paul Cartledge summed it up, 'Greekness had relatively little impact in the sphere of practical politics...there were well over a thousand separate Greek political communities who could never form more than local, shortlived, and usually imposed interstate ties' (1993: 3). Indeed, during the war against the 'Persian' Empire, the event that is so frequently invoked as evidence of ancient pan-Hellenic nationalism, only thirty-one out of the seven hundred or more poleis in mainland Greece and the Aegean agreed on oath to fight together. Tellingly, more 'Greeks' are believed to have fought on the 'Persian' than 'Greek' side (Cartledge 2009: 200).

\section{The Conflation of Culture with Identity}

Analysts who conflate culture with identity misunderstand ethnic or national consciousness as necessarily equivalent to the routine practices that constitute culture. By assuming these core sociological concepts are interchangeable, analysts introduce a false ascriptiveness into the narrative. They equate the historical presence of a culture with the historical presence of ethnic or national identification during periods when alternative identities were conjoined to the culture in question. 
While culture can, and frequently does, overlap with identity, they are not necessarily equivalent. Culture is the 'publically available symbolic forms through which people experience and express meaning' (Swidler, 1986: 273). These can consist in beliefs, ritual practices, art forms, ceremonies, language, gossip, stories, and rituals of daily life (Swidler 1986: 273). By contrast, identity is an aspect of a relationship (Eriksen 2002: 34, 36, 37) and, crucially, a phenomenon that is underpinned by ascription (Patten 2011: 745). That is, a particular identity exists to the extent that its bearer - an individual or collectivity - is classifying itself as distinct and is recognised as distinct by significant others.

Understood in these terms, culture and identity can coincide. But this correspondence is an empirically contingent, rather than logical one, as culture can be present without identity and identity without culture. Whenever the two phenomena overlap, one considers oneself a member of a particular culture, values this membership, cares about the success of that culture, and lets that culture count as a factor in one's practical reasoning. By contrast, whenever identity is detached from culture, one neither identifies, nor is identified by others, with the beliefs and practices into which one has been socialised. Instead, these practices are met with indifference and sometimes even with disdain (Patten 2011: 745).

The importance in maintaining this analytical separation is that it allows continuity of ethnic and national identity to be understood as a continuity of self-awareness and 
continuity of culture to be understood as a continuity of beliefs and practices. This insight draws attention to the reality that the perpetuation or interruption of each of these social phenomena can occur independently of the other. Differences of culture translate into differences of identity if and only if such differences have acquired relevance during social interaction (Eriksen 2002: 38). There is nothing ethnically or nationally intrinsic to a given culture.

The failure to appreciate the sociological distinction between culture and identity is how the genealogy of present day ethno-nations come to be overextended. The concepts are treated as one and the same. Consequently, the analyst is oblivious to the varied subjectivities attached to a particular culture over time, misunderstanding the culture as constantly ethnic or national.

This oversight opens up a nonsensical line of inquiry about authenticity in which it is presumed the 'true' identity of a population can be ascertained apriori from deductions based on cultural attributes. In taking this approach, the analyst miscomprehends identity as a phenomenon that exists outside the awareness and disclosure of the subjects under observation. He/she sees no need for phenomenological inquiry to determine how people understand themselves from their own point of view. Differences of culture hold the key to questions of ethnonational classification, given that certain cultures are viewed as archetypically ethnic or national. 
Misha Glenny's (1993) writing on Yugoslavia is illustrative. His assumption that identity is something that can be decoded from the morphology of a culture leads him to mischaracterise transformations of religious faith among Ottoman era populations as transformations of ethnonational belonging. Speaking in the context of Bosnia, he asserts: 'Yugoslavia's Moslems [Bosniaks] are Serbs and Croats who were converted by the Turks and have now lost their original ethnic identity' (129).

Glenny is referring to the conversions from Christianity to Islam that Slavic populations underwent during Ottoman rule. However, to ponder the 'originality' of ethnicities during this event is to engage in idle speculation, as socialisation in religious culture did not condition ethnic self-awareness until more recently. Indeed, it is only over the last century that religious acculturation has functioned as a determinant of ethnic and national identification in Bosnia. In this period, Orthodox populations began to identify with a Serbian nation, Catholics with a Croatian nation, and Muslims with a Muslim or Bosniak nation as religious distinctions acquired an overriding importance in the ideologies of competing nation-building programs (Bringa 1995: 28).

By confusing a moral belief system based on religion with self-awareness based on ethnic descent, Glenny is backdating the nation. He is also restating the views of 
nationalist scholars and media commentators in Serbia and Croatia asserting that only Serbian and Croatian nationhood is natural and that Bosniaks are an invented people.

The same problematic leap from culture to identity is witnessed in the work of Ivo Banac (1988), only he singles out language, rather than religion, as the overriding cultural determinant of ontological authenticity. As he asserts: 'Cultural attributes [original italics], above all language, are decisive' for understanding what it means to be a 'nation' (22). This is so because, in his view, 'even from the earliest times language was a synonym for a national community' (22).

Banac applies these assumptions to south Slavic nations, grouping them dualistically into ultimate and degenerate types. 'Bulgars', 'Croats' and 'Serbs', he asserts, are 'old South Slavic nations' (23) with inherent linguistic features observable well before the era of nationalism. 'Medieval Croats' are supposed to have spoken the 'čakavian, kajkavian, and old western štokavian' dialects, and 'medieval Serbs', the 'eastern štokavijan and Torlak' dialects (47). What is more, the distribution of these speech patterns is supposed to have pinpointed the location of 'purely Croat areas' and 'the original Serbia': the former apparently extended into the 'Bosnian principality', the latter was 'far from the Danube' $(33,39)$. Banac contrasts these apparently enduring peoples with 'Slovenes', 'Montenegrins', 'Macedonians' and 'Bosnian-Herzegovinian Muslims'. He terms these identities 'new South Slavic nations', contending they 
'acquired a national consciousness only in the nineteenth century' or are 'twentieth century mutations...still in the process of formation' (23).

Banac does not normatively defend his negative evaluation of 'new nations' as congenital defects. However, it is evident that his one-sided pathologising stems from the belief that 'old nations' are constituted by cultures with an essential nature and that other nations must therefore originate through a distortion of this unadulterated state. Put simply, Banac is implying that some nations have their own independent reality, irreducible to anything else, and that other nations do not.

However, taking recourse to linguistic features to prove the authenticity of Slavic nations is a futile exercise in tautological justification. One might be able to locate differences in dialects and proceed to specify the boundaries of Slavic nations according to those differences. But this merely returns us to the question of what is specifically national about those dialects. In this ontological circle, the dog is simply chasing its tail. The conclusion is drawn before the analysis has even begun, as a preliminary decision has been made that certain speech patterns have an intrinsically national character.

An appreciation is gained of just how flawed a tool linguistic difference is for laying down the historical contours of nations and proving that some nations are older than 
others by considering the deliberate actions taken to create, disseminate or repackage languages that are today unquestioningly accepted as national.

Prior to the era of nationalism, it was rare to witness languages being systematically imposed on people in order to bring them together and demarcate them from others (Anderson 2006: 42). Language acculturation was a choice largely left to individuals. In this climate of linguistic indifference, societies tended to be characterised by diglossias, consisting in, on the one hand, grammatically regulated high languages that were spoken and written in official circles and, on the other hand, various spontaneous languages that were spoken at home and in the streets (Leonhardt 2013: 201-202).

Importantly, neither of these communicative forms were experienced as belonging to a 'people'. High languages, such as Latin, Classical Greek, Old Church Slavonic, Ottoman Turkish, and High Arabic did bear some resemblance to today's standardised national languages in that they were codified according to established norms signalling correctness in speech and writing. Nevertheless, high languages remained the preserve of social elites, rather than the population at large. Fluency in them required academic training and they functioned as primary mediums of exchange in administration, scholarship, literature, commerce and liturgy, but not in ordinary conversation. 
A similar point can be made about the non-national character of everyday vernaculars. On the one hand, they shared with today's national languages the property of being native tongues. They were, after all, first-languages, rather than learner-languages, and had a range that extended across the masses. On the other hand, vernacular speech was fundamentally different to today's national languages in the sense of being unregulated. It was not structured by agreed upon norms that functioned as arbiters of communicative correctness. Nor was it the basis of written communication, an activity that was by and large carried out in the high languages. Owing to its linguistic anarchy, vernacular speech lacked the internal uniformity characteristic of the codified languages that are claimed by today's national communities. Instead, it was an amalgam of blended differences, whereby rates of intelligibility increased or decreased depending on the distance from one's place of linguistic acculturation (Billig 1995: 30-31).

Importantly, vernacular speech was rarely a site of interest formation and contestation. It did not typically give rise to language communities with an enduring political sense of themselves and a capacity or desire to pursue goals in opposition to one another. As Billig sums it up, people would not 'have dreamt of ever going to war over such matters'. Although they spoke, they did not perceive themselves 'to speak something - a language' (1995:31). Relative to today's compartmentalised world of linguistically regulated communities, the past was 'an unbelievably messy, disorganised place' (21), unobsessed with the preservation of speech boundaries. 
It was only with the appearance of nationalism that language assumed its familiar ideological functions of nurturing collective attachments and sustaining political communities. In this period, languages underwent a process of nationalisation. Writers and intellectuals in search of the nation's 'soul' elaborated language norms as part of that mission. These norms were subsequently made binding by governmental decree. They became compulsory rules of speech in the public institutions and spaces of newly emerged nation-states, giving rise to official languages that could be claimed as belonging to the entire citizenry (Leonhardt 2013: 225).

A further problem with the use of linguistic characteristics to detect nations in the past is that language standardisation policies have not always been a surface manifestation of nationalism or a pursuit motivated by the desire to meet a national identity need. The forces and intentions at play have varied across moments and locations. Thus, as Ernest Gellner pointed out, during the transition towards industrial systems of production, economic objectives intermingled with or preceded nationalising ones in the quest for linguistic uniformity. Here, the introduction of compulsory languages was a means to achieving society-wide literacy. This, in turn, equipped states with a uniform communicative medium necessary for the high degree of labour mobility and technical competence inherent to an industrial economy (2008: 33-37). 
In other instances, the production of linguistic uniformity served religious purposes. Sub-Saharan Africa is a case in point. Written traditions emerged there as a result of missionary investments by Protestants during the nineteenth century, who formalised indigenous languages and printed Bibles and educational material in these languages wherever they settled (Cagé and Rueda 2016: 72). The primary motivation of these activities was spiritual, and not national, imperialism. The intention was to spread Christianity into newly acquired colonies and realise the Sola Scriptura principle that 'every Protestant should be capable of reading and interpreting the Bible' (Cagé and Rueda 2016: 72).

\section{Ethnicity as Methodological Nationalism by the Back Door}

In this final section, I explore the implications of my arguments from the standpoint of ethnicity. I explain why it is mistaken to contend that some of today's nations existed as ethnic communities prior to the era of nationalism (e.g., Smith 2004; Gat 2012) and conclude by offering suggestions on how to avoid methodological nationalism when adopting social categories to represent historical populations.

On the one hand, ethnicity - a type of collective belonging premised on perceptions of shared cultural inheritance or biological descent - is conceptually distinguishable from nationhood - a type of collective belonging premised on a desire to exercise control over a state. On the other hand, it is easy to put too fine a point on this 
distinction when making claims about the empirical world. After all, each identity concept shares the feature of referring to a supralocal scale of communal togetherness (Breuilly 1996: 153). Furthermore, national communities are always more or less ethnic, rather than completely removed from an ethnic rationale. Put differently, like its national variant, ethnicity denotes an experience of solidarity that transcends the small-scale and intimate affinities of face-to-face settings to encompass a societywide kinship based on anonymous membership. It differs from its nationalist variant only by virtue of being decoupled from a desire for statehood.

Yet there is no specific evidence that such an expansive sense of 'us' and 'them' had overriding significance for people before the age of nationalism. Nor is there any reason to infer it, as the socialising apparatus necessary for making ethnic togetherness an imperative aspect of individual and communal personhood was absent (Breuilly 1996: 153). To be sure, institutions did exist that were capable of standardising collective experience beyond the local level, such as churches and dynasties. However, as noted above, their primary concern was establishing the dominance of religious doctrine or ideas of civilisation, rather than spreading the ideologies of common origin and endogamy required for ethnic distinctions to have salience and mass appeal.

Caution should therefore be exercised when coding populations and political entities to avoid attributing misleadingly the boundary consciousness and agency of 
nationhood via the cognate concept of ethnicity. Authors may find it convenient to categorise the pre-national past through catch-all labels that have ethnonational meaning in the present. They may, for example, judge such terminological choices as the 'French' and 'Spanish' Kingdoms or the 'German' inhabitants of the Holy Roman Empire to be the least cumbersome short-hands for carving up a medieval context that was socially and politically complex in order to make palpable claims about what happened there. However, language plants ideas about things, and the use of ethnonationally loaded terminology - compact and workable as it may be - unjustifiably casts populations as certain types of actors. It gives the erroneous impression that ethnicity was worn as a primary badge of identification, that it was a basic constituent of social and political life, that it gave rise to internally homogenous groups with clear boundaries, and that such groups were chief protagonists of conflict (Brubaker 2002: 164).

What entails proper coding is an open question, as all coding choices are inescapably essentialising. To demarcate a unit of analysis is to formulate rigid inside-outside distinctions between clusters of people supposedly sharing stable and uniform attributes. Such analytical boundary-making can never do justice to the fluid and multifarious nature of social relations. Consequently, the process will always be imperfect and contested, rather than lead to the discovery of unifying concepts that capture absolutely the complexities of empirical reality. 
Put differently, categories are choices between different kinds and degrees of simplification, choices, moreover, one is forced to make in order to begin thinking and speaking about the social world. Making judgements between such choices requires evaluating which is most suited to understanding the phenomenon under investigation. Such judgements are ideally reviewed and potentially revised as the contingencies of research arise.

Nevertheless, while all classifications are more or less essentialising, steps can be taken to ensure they do not erroneously portray ethnicity to be at work in the historical context they are coined to describe. At the very least, a distinction ought to be made between 'categories of practice' and 'categories of analysis' (Brubaker 2013), especially when terminological choices carry strong ethno-national connotations. The former categories are ontological statements according to the epistemic and symbolic experience of people within the historical world being represented. The latter categories are sense-making instruments the observer deploys to array episodes in that world according to his/her own epistemic and symbolic experience and his/her own judgements about what eases the cognitive load of producing and grasping such knowledge.

Writing that maintains and clearly communicates a distinction between these two conceptual functions has a better chance of maintaining narrative integrity. 
It avoids the mistake of sliding between disclosures of identity from the first-person perspective (category of practice) and heuristic devices introduced into the field of investigation to aggregate populations according to predefined traits (category of analysis).

The upshot is that simplifying labels like 'German-speakers' or 'Germanic inhabitants' can be used in a non-distortive manner whenever linguistic traits are judged to be important for describing and explaining events in Holy Roman Empire. By making it clear that those labels are not empirical statements about how affinity and connectedness were experienced, but rather, cognitive shortcuts for synthesising a bewildering number of facts into a coherent account of what the past was like, the author avoids perpetuating the undocumented assertion that 'Germanness' was an acculturation doctrine or that it formed the basis of community for the vast and deeply diverse populations captured by those labels.

Methodologically transparent and reflexive writing of this kind would also stress the heterogeneity present within chosen categories of analysis. It would, for example, specify that appellations like 'German speakers' and 'Germanic inhabitants' in the context of the Holy Roman Empire denote a collection of people distinguishable by vast language differences, rather than a linguistically homogenous bloc. It would also convey that before nationalist pedagogy was systematically implemented less than two centuries ago, only the very well educated among these people could make 
themselves mutually understandable when conversing in 'German dialects' from distant regions (Leonhardt 2013: 225).

Under this formula, authors avoid becoming 'analytical naturalisers' (Brubaker 2002: 169). They are making evident the value-laden decisions and arbitrariness behind their frames of reference. Bordered thinking is not completely overcome and the problem of reification is not countervailed. However, agent-like properties are not projected onto populations without proof. A sequence of events can be described without giving nations a covert significance, as the developmental pathways under which national identification eventually acquired a special salience are represented as moving along trajectories that were multiple and unforeseeable, rather than fixed to known national places.

\section{Conclusion}

Methodological nationalism is a research practice that institutionalises a particular narrative bias in recollections of the past. It perpetuates the nation as immanent in history through an initial proposition that nations are an obvious level of description and explanation. By embodying this choice of abstraction, methodological nationalism does not innocently reflect on the world out there. Rather, it brings populations into being, constituting them as tangible and quantifiable entities with agential properties (Scheel et al. 2016: 3). Whenever these representations become the 
starting point of subsequent research, they have transmitted and amplified the selfevidence of national actors as a window onto the historical world.

Taking as examples work that gives nations a retrospective significance in ancient and medieval recorded history, I have highlighted four practices that are a part of this reinforcement loop and made a plea to resist being drawn in by their expectations to think and write a certain way. With its mishandling of facts and flights of fancy, research of this kind hides radical discontinuities, generates narrative smoothness, and ultimately, assigns nations with a given character. To the extent that it 'creates the very reality it appears to describe' (Said 2003: 94), such research distorts knowledge and should be rejected as a flawed way of representing the past.

\section{References}

Anderson, B. 2006. Imagined Communities: Reflections on the Origin and Spread of Nationalism. 2nd edn. London: Verso.

Banac, I. 1988. The National Question in Yugoslavia: Origins, History, Politics. Ithaca: Cornell University Press.

Beck, U. 2000. What is Globalization? Cambridge: Polity Press.

Beck, U. 2002. 'The Terrorist Threat: World Risk Society Revisited', Theory, Culture and Society 19, 4: 39-55. 
Beck, U. and Sznaider, N. 2010. 'Unpacking Cosmopolitanism for the Social

Sciences: A Research Agenda', The British Journal of Sociology 61, 1: 381-403.

Berger, S. with Conrad, C. 2015. The Past as History: National Identity and

Historical Consciousness in Modern Europe. Basingstoke: Palgrave Macmillan.

Billig, M. 1995. Banal Nationalism. London: Sage.

Breuilly, J. 1993. Nationalism and the State. 2nd ed. Manchester: Manchester University Press.

Breuilly, J. 1996. 'Approaches to Nationalism' in G. Balakrishnan (ed.), Mapping the Nation. London: Verso.

Breuilly, J. 2008 'Aviel Roshwald's The Endurance of Nationalism' in A. Smith, J. Breuilly, M. Grant, and A. Roshwald, 'Fourth Nations and Nationalism Debate on Aviel Roshwald's The Endurance of Nationalism', Nations and Nationalism 14, 4: 639-643.

Bringa, T. 1995. Being Muslim the Bosnian Way: Identity and Community in a Central Bosnian Village. Princeton: Princeton University Press.

Brubaker, R. 2002. 'Ethnicity without Groups', European Journal of Sociology 43, 2: 163-189.

Brubaker, R. 2013. 'Categories of Analysis and Categories of Practice: A Note on the Study of Muslims in European Countries of Immigration', Ethnic and Racial Studies 36, 1: 1-8

Cagé, J. and Rueda, V. 2016. 'The Long-Term Effects of the Printing Press in subSaharan Africa', American Economic Journal 3, 3: 69-99. 
Caroll, L. 1990. Through the Looking Glass. New York: Random House.

Cartledge, P. 1993. The Greeks: A Portrait of Self and Others. Oxford: Oxford University Press.

Cartledge, P. 2009. Ancient Greece: A History in Eleven Cities. Oxford: Oxford University Press.

Collier, D. 1995. 'Translating Quantitative Methods for Qualitative Researchers: The Case of Selection Bias', American Political Science Review 68, 2: 461-466.

Danforth, L.M. 1995. The Macedonian Conflict: Ethnic Nationalism in a Transnational World. Princeton: Princeton University Press.

Dryzek, J. 1988. 'The Mismeasure of Political Man', The Journal of Politics 50, 3 : $705-726$.

Eriksen, T.H. 2002. Ethnicity and Nationalism. 2nd edn. London: Pluto Press.

Gat, A. 2012. Nations: The Long History and Deep Roots of Political Ethnicity and Nationalism. Cambridge: Cambridge University Press.

Gellner, E. 2008. Nations and Nationalism. 2nd ed. Ithaca: Cornell University Press.

Glenny, M. 1993. The Rebirth of History: Eastern Europe in the Age of Democracy. 2nd ed. London: Penguin.

Greene, M. 2015. The Edinburgh History of the Greeks, 1453 to 1768: The Ottoman Empire. Edinburgh: Edinburgh University Press.

Grosby, S. 2005. Nationalism: A Very Short Introduction. Oxford: Oxford University Press. 
Hansen, L. 2006. Security as Practice: Discourse Analysis and the Bosnian War. Oxon: Routledge.

Hastings, A. 1997. The Construction of Nationhood: Ethnicity, Religion and Nationalism. Cambridge: Cambridge University Press.

Held, D. 2006. Models of Democracy. 3rd ed. Cambridge: Polity.

Hirschi, C. 2012. The Origins of Nationalism. An Alternative History from Ancient Rome to Early Modern Germany. Cambridge: Cambridge University Press.

Hörnqvist, M. 2004 Machiavelli and Empire. Cambridge: Cambridge University Press.

Huntington, S.P. 1993. 'The Clash of Civilizations', Foreign Affairs 72, 3: 22-49.

Kaldellis, A. 2007. Hellenism in Byzantium: The Transformation of Greek Identity and the Reception of the Classical Tradition. Cambridge: Cambridge University Press.

Kaplan, R.D. 2005. Balkan Ghosts. rev edn. New York: Picador.

Lawrence, P. 2013. 'Nationalism and Historical Writing', in J. Breuilly (ed), The Oxford Handbook of the History of Nationalism. Oxford: Oxford University Press.

Leerssen, J. 2014. 'The Baton and the Frame: Or, Tradition and Recollection' in Grosby, S., Leerssen, J. and Hirschi, C. 'Continuities and Shifting Paradigms: A Debate on Caspar Hirschi's The Origins of Nationalism', Studies in National Movements 2: 1-48. 
Leonhardt, J. 2013. Latin: Story of a World Language. Cambridge: Harvard University Press.

Miller, D. 2008. 'Immigrants, Nations and Citizenship', The Journal of Political Philosophy 16, 4: 371-390.

Özkirmli, U. 2007. 'The "Perennial" Question: Nations in Antiquity or the Antique Shop of History?' in Özkirmli, U. and Grosby, S. 'Nationalism Theory Debate: The Antiquity of Nations?', Nations and Nationalism, 13, 3: 523-529.

Özkirmli, U. and Sofos, S.A. 2008. Tormented by History: Nationalism in Greece and Turkey. London: Hurst Publishers.

Patten, A. 2011. 'Rethinking Culture: The Social Lineage Account', American Political Science Review 105, 4: 735-749.

Roshwald, A. 2006. The Endurance of Nationalism: Ancient Roots and Modern Dilemmas. Cambridge: Cambridge University Press.

Sager, A. 2016. 'Methodological Nationalism, Migration and Political Theory', Political Studies 64, 1: 42-59.

Said, E. 2003. Orientalism. rev edn. London: Penguin.

Sand, S. 2010 The Invention of the Jewish People. London: Verso.

Sartori, G. 1970. 'Concept Misformation in Comparative Politics', American Political Science Review 64, 4: 1033-1053.

Scheel, S., Cakici, B., Grommé, F., Ruppert, E., Takala, V. and Ustek-Spilda, F. 2016. Transcending Methodological Nationalism through a Transversal Method? On the Stakes and Challenges of Collaboration', Arithmus 1: 1-36. 
Skinner, Q. 1969. 'Meaning and Understanding in the History of Ideas', History and Theory 8, 1: 3-53.

Smith, A.D. 1991. National Identity. London: Penguin

Smith, A.D. 2004. 'Dating the Nation' in Conversi, D. (ed) Ethnonationalism in the Contemporary World. London: Routledge.

Storm, E. 2017. 'The Nationalisation of the Domestic Sphere', Nations and Nationalism 23, 1: 173-193.

Storm, E. 2018. 'A New Dawn in Nationalism Studies? Some Fresh Incentives to Overcome Historiographical Nationalism', European History Quarterly 48, 1: $113-129$.

Swidler, A. 1986. 'Culture in Action', American Sociological Review 51, 2: 273-286.

Wimmer, A. 2013. Waves of War: Nationalism, State Formation, and Ethnic Exclusion in the Modern World. Cambridge: Cambridge University Press.

Wimmer, A. and Schiller, N.G. 2003. 'Methodological Nationalism, the Social Sciences, and the Study of Migration: An Essay in Historical Epistemology', International Migration Review 37, 3: 576-610.

Wittgenstein, L. 1922. Tractatus Logico-Philosophicus. London: Kegan Paul, Trench, Trubner \& Co., Ltd.

Woolf, D. 2007. 'Of Nations, Nationalism, and National Identity: Reflections on the Historiographic Organization of the Past' in Q.E. Wang and F.L. Fillafer (eds.), The Many Faces of Clio: Cross-Cultural Approaches to Historiography. Essays in Honour of George G. Iggers. New York: Berghahn. 


\section{University Library}

\section{- M M N E R VA A gateway to Melbourne's research publications}

Minerva Access is the Institutional Repository of The University of Melbourne

Author/s:

Vasilev, $\mathrm{G}$

Title:

Methodological nationalism and the politics of history-writing: how imaginary scholarship perpetuates the nation

Date:

2019-04-01

\section{Citation:}

Vasilev, G. (2019). Methodological nationalism and the politics of history-writing: how imaginary scholarship perpetuates the nation. NATIONS AND NATIONALISM, 25 (2), pp.499-522. https://doi.org/10.1111/nana.12432.

Persistent Link:

http://hdl.handle.net/11343/285020 